OPEN

SUBJECT AREAS:

AGRI-ECOLOGY

INVASIVE SPECIES

BEHAVIOURAL ECOLOGY

Received

8 January 2014

Accepted

13 June 2014

Published

6 August 2014

Correspondence and requests for materials should be addressed to

S.W. (wangshaoli@

caas.cn) or X.Z.

(xuguozhou@uky.edu)

\section{Effects of plant virus and its insect vector on Encarsia formosa, a biocontrol agent of whiteflies}

\author{
Xiaoyuan Liu',2, Wensheng Xiang ${ }^{2}$, Xiaoguo Jiao', Youjun Zhang ' ', Wen Xie' ', Qingjun Wu' ', Xuguo Zhou ${ }^{3}$ \\ \& Shaoli Wang'
}

\begin{abstract}
'Department of Plant Protection, Institute of Vegetables and Flowers, Chinese Academy of Agricultural Sciences, Beijing, 100081, P. R. China, ${ }^{2}$ Department of Life Science, Northeast Agricultural University, Harbin 150030, P. R. China, ${ }^{3}$ Department of Entomology, University of Kentucky, Lexington, KY 40546-0091, U.S.A.
\end{abstract}

In this study, we investigated the tritrophic interactions among a persistently transmitted plant virus, Tomato yellow leaf curl virus (TYLCV), its insect vector, the sweetpotato whitefly Bemisia tabaci, and a parasitoid, Encarsia formosa Gahan, one of the most extensively used biological control agents. As an emerging invasive pest worldwide, the two most damaging whiteflies are B. tabaci $B$ and $Q$ cryptic species. On healthy tomato plants, parasitoid-induced mortality was significantly higher in B. tabaci B than in Q. In contrast, similar mortality levels of B and Q were observed on TYLCV-infected plants. A higher rate of parasitism was consistently observed in B, independent of the TYLCV infection. Similarly, the life history traits of $E$. formosa were influenced by both TYLCV and the two cryptic species of $B$. tabaci. Specifically, $E$. formosa parasitizing $B$ had a greater adult longevity and shorter developmental time on healthy plants, whereas the parasitoids developing from $\mathrm{Q}$ has a greater adult longevity on TYLCV-infected plants. The emergence rate of $E$. formosa was unaffected by either $B$. tabaci cryptic species or the virus. These results suggest that the vector-borne pathogen can manipulate the host suitability of a parasitoid and hence the parasitoid-host interactions.

. he sweetpotato whitefly, Bemisia tabaci (Gennadius) (Homoptera: Aleyrodidae), attacks many economically important crops, including vegetables, cotton, and ornamentals. Recent studies suggest that $B$. tabaci is a species complex containing at least 24 morphologically indistinguishable cryptic species ${ }^{1-3}$. The two most invasive and widespread groups of B. tabaci are the Middle East-Asia Minor I species (referred to as B hereafter) and the Mediterranean species (referred to as Q hereafter) ${ }^{1-3}$. The B. tabaci B was first recorded in China in the early 1990s, and it subsequently spread throughout much of the country, but has been recently displaced by Q in many areas ${ }^{4,5}$.

Although B. tabaci can damage crops directly by feeding, it causes greater damage by transmitting over 100 begomoviruses that can have catastrophic impacts on plant growth and survival ${ }^{3}$. Tomato yellow leaf curl virus (TYLCV) is a single-stranded DNA plant virus that originated in the Middle East ${ }^{6}$. TYLCV is transmitted by $B$. tabaci, the only known vector, in a circulative, persistent manner ${ }^{7}$ TYLCV was first detected in Shanghai, China in $2006^{8}$ and then quickly spread from the Southern to Northern parts of China'. Although both B and Q can vector TYLCV horizontally, Q exhibited a much higher efficiency than B; as a result, Q appears to be a more competent viral vector than $\mathrm{B}^{9-11}$. The spread of TYLCV coincided with the rapid displacement of the B. tabaci $\mathrm{B}$ by $Q$ in China ${ }^{9}$. Because both cryptic species have developed resistance to various synthetic insecticides, especially in $\mathrm{Q}^{12,13}$, biological control is one of the best alternatives available for the sustainable management of $B$. tabaci populations.

Encarsia formosa Gahan (Hymenoptera: Aphelinidae) is a solitary endoparasitoid that has been used commercially for the biocontrol of whiteflies, including the sweetpotato whitefly B. tabaci and the greenhouse whitefly Trialeurodes vaporariorum, worldwide ${ }^{14}$. As one of the most extensively used natural enemies, E. formosa parasitizes at least fifteen species of whiteflies in eight genera ${ }^{14}$. Specially, adult females parasitize and kill whitefly nymph, although the developmental time of E. formosa depends on the developmental stage of $B$. tabaci nymph ${ }^{15}$.

Bemisia tabaci Q has now become the primary whitefly cryptic species in China ${ }^{4,5}$, and as noted, the rapid spread of Q has been accompanied by the recent outbreaks of TYLCV 9 . Information regarding the tritrophic interactions among TYLCV, a persistently transmitted plant virus, $B$. tabaci, the only known insect vector, and $E$. 

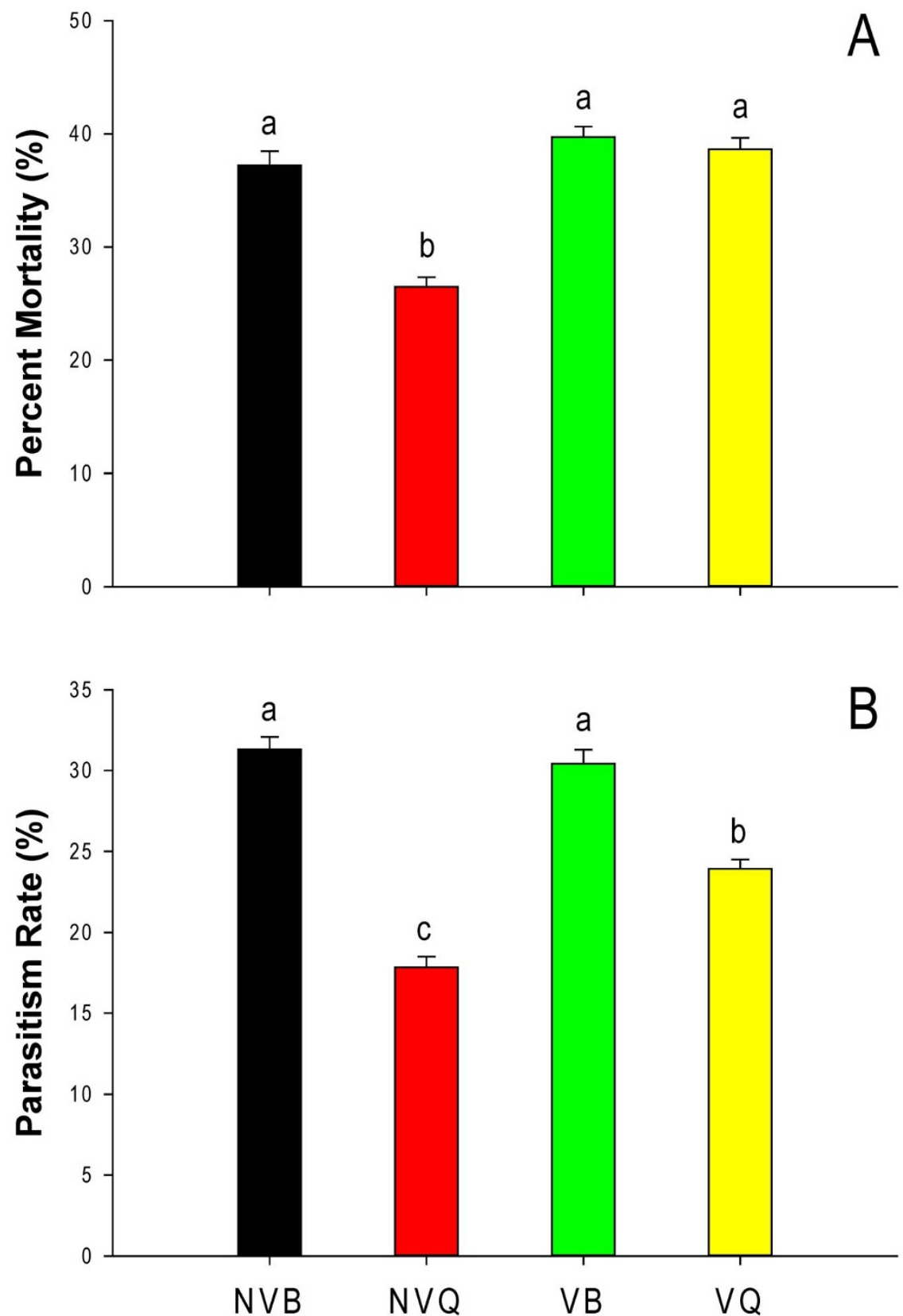

Figure $1 \mid$ Biocontrol properties of $E$. formosa on the sweetpotato whitefly B. tabaci. The $3^{\text {rd }}$ instar nymphs of $B$. tabaci B and Q cryptic species were reared on healthy $(\mathrm{NV})$ and TYLCV-infected tomato plants (V), respectively, before submitting them to a hymenopterous parasitoid, E. formosa. The percent mortality (A) and the parasitism rate (B) of B. tabaci were documented. Values (means \pm SE) are from three biological replications. Within each panel, different letters indicate significant differences among treatments $(\mathrm{P}<0.05)$.

formosa, the primary biocontrol agent for whiteflies, are grossly lacking. In this study, we are specifically investigating the impacts of this virus and its insect vector on the performance and life history traits of E. formosa. A better understanding of such interactions will, in turn, offer valuable insight into the long-term sustainable control of whiteflies, with or without the occurrence of epidemic plant virus.

\section{Results}

Biocontrol properties of $E$. formosa on the sweetpotato whitefly $B$. tabaci. The mortality rate of $E$. formosa was significantly affected by the $B$. tabaci cryptic species $\left(\mathrm{F}_{3,236}=34.759, \mathrm{P}<0.0001\right)$, virus infection status $\left(\mathrm{F}_{3,236}=54.068, \mathrm{P}<0.0001\right)$, and the interaction between the two $\left(\mathrm{F}_{3,236}=23.432, \mathrm{P}<0.0001\right)$. The mortality rate was significantly lower in Q reared on healthy plants than in $\mathrm{B}$ reared on healthy plants or in either B or Q reared on TYLCV-infected plants (Figure 1A, Figure S1).

The parasitism rate was significantly affected by the $B$. tabaci cryptic species $\left(\mathrm{F}_{3,236}=190.939, \mathrm{P}<0.0001\right)$, virus infection status $\left(\mathrm{F}_{3,236}=15.896, \mathrm{P}<0.0001\right)$, and the interaction between the two $\left(\mathrm{F}_{3,236}=27.190, \mathrm{P}<0.0001\right)$. The parasitism rate was significantly lower in Q reared on healthy plants than in B reared on healthy plants or in either B or Q reared on TYLCV-infected plants. In addition, the parasitism rate was lower in Q reared on TYLCV-infected plants than in B reared on healthy or TYLCV-infected plants (Figure 1B, Figure S1).

The impacts of TYLCV and B. tabaci cryptic species on the life history traits of $\boldsymbol{E}$. formosa. The developmental time of $E$. formosa was significantly affected by the virus infection status $\left(\mathrm{F}_{3,236}=\right.$ 
10.960, $\mathrm{P}=0.001)$ and the interaction between $B$. tabaci cryptic species and virus infection status $\left(\mathrm{F}_{3,236}=11.954, \mathrm{P}=0.001\right)$, but was not significantly affected by $B$. tabaci cryptic species $\left(\mathrm{F}_{3,236}=\right.$ 3.640, $\mathrm{P}=0.058$ ). Developmental time was shorter in $\mathrm{B}$ reared on healthy plants than on TYLCV-infected plants or Q reared on either healthy plants or TYLCV-infected plants. But it was not significantly different among B reared on TYLCV-infected plants or Q reared on either healthy plants or TYLCV-infected plants (Figure 2A, Figure $\mathrm{S} 2$ ).

The emergence rate of $E$. formosa, i.e., the percentage of pupae from which adult wasps emerged, was not significantly affected by $B$. tabaci cryptic species $\left(\mathrm{F}_{3,236}=0.723, \mathrm{P}=0.396\right)$, virus infection status $\left(\mathrm{F}_{3,236}=0.238, \mathrm{P}=0.626\right)$, or the interaction between the two $\left(\mathrm{F}_{3,236}=2.239, \mathrm{P}=0.136\right)$ (Figure $2 \mathrm{~B}$, Figure $\mathrm{S} 2$ ).

The longevity of $E$. formosa was significantly affected by the $B$. tabaci cryptic species $\left(\mathrm{F}_{3,236}=6.086, \mathrm{P}=0.014\right)$, virus infection status $\left(\mathrm{F}_{3,236}=80.644, \mathrm{P}<0.0001\right)$, and the interaction between the two $\left(\mathrm{F}_{3,236}=294.839, \mathrm{P}<0.0001\right)$. Longevity was significantly shorter in Q reared on healthy plants than on TYLCV-infected plants or B reared on either healthy plants or TYLCV-infected plants. In addition, the longevity of $E$. formosa parasitizing $B$. tabaci $\mathrm{Q}$ from the TYLCV-infected tomato was significantly higher than those wasps parasitized whiteflies from the TYLCV-free tomato. In case of $B$. tabaci B, however, the trend was reversed (Figure 2C, Figure S2).

\section{Discussion}

The influence of insect vector on the performance and fitness of $E$. formosa. Although parasitism of $B$. tabaci by E. formosa has been studied previously ${ }^{16-18}$, none of them has been focused on the potential impact of cryptic species. As the most invasive and destructive B. tabaci cryptic species, B and Q vary in their mating and feeding behavior and prefer different host plants ${ }^{10,19,20}$. On healthy tomato plants, E. formosa performed better (higher mortality and parasitism rates) on B. tabaci B than on Q (Figure 3). This is consistent with the results from a congeneric parasitoid, $E$. sophia ${ }^{21}$. In regard to fitness, the developmental times of E. formosa on the $3^{\text {rd }}$ instar nymphs of B. tabaci were 14.16 and 14.52 days, respectively for B and Q. A similar trend was documented in $E$. sophia, in which the developmental time of the parasitoid on $B$. tabaci $\mathrm{B}$ and $\mathrm{Q}$ were not significantly different ${ }^{21}$. Similarly, the emergence rate of E. formosa was not significantly affected by the two cryptic species. As for adult longevity, however, E. formosa lived longer in B than in Q. The combined results from parasitoid's performance and fitness indicate that B. tabaci $\mathrm{B}$ is a more suitable host for the Encarsia spp. than Q, although the underlying mechanisms are largely unknown. The E. formosa colony was obtained initially from the United Kingdom and was introduced into the vegetable-growing areas in China to control whiteflies in the 1980s. E. formosa has been acclimated into the field conditions in China for over 30 years, and experienced the invasions of $B$. tabaci B and Q in the 1990s and 2000s, respectively ${ }^{22}$. By 2011, Q had displaced B and become the dominant cryptic B. tabaci species in most areas in $C_{\text {China }}^{5,23}$. The present study suggests that parasitic E. formosa is more effective against B. tabaci B than against $\mathrm{Q}$, and this difference in their suitability for the parasitoid could partially contribute to the competitive displacement of B. tabaci B by Q in China.

The impact of virus infection of the host plant on the performance and fitness of $\boldsymbol{E}$. formosa. Virus induced plant responses can influence the behavior and physiology of insect vectors, and, sometimes, lead to behavioral changes in the vectors that favor viral transmis$\operatorname{sion}^{24,25}$. Although tritrophic interactions among vector-borne pathogens, its vector, and the parasitoid (E. formosa) add another layer of complexity, it is germane to speculate that vector-borne pathogen can exert its impact on a parasitoid through the vector. Multiple lines of evidence have shown that TYLCV can manipulate the behavior (e.g. host preference) of its exclusive vector, B. tabaci species complex, for the benefit of viral transmission ${ }^{9,10,26,27}$. TYLCVinfected whiteflies fed more readily than uninfected individuals and spent more time salivating, which is essential for the spread of a persistently transmitted plant virus ${ }^{10}$. Field surveys indicate an apparent mutualistic relationship between the outbreaks of TYLCV and the introduction and rapid range expansion of $B$. tabaci $\mathrm{Q}^{5}$. Plant defensive compounds, specifically terpenoids, play a key role in mediating vector-pathogen mutualistic relationships. Gas chromatography-mass spectrometry (GCMS) analysis showed that healthy plants released significantly more terpenoids than TYLCV-infected plants ${ }^{26}$. The higher level of terpenoids, a suite of defensive compounds from plants, however, compromised the fitness level of $B$. tabaci. Suppression of terpenoid synthesis pathway via gene silencing, in return, enhanced the fitness level of B. tabaci $^{27}$. That means TYLCV can influence host-derived cues in ways that have positive effects on vector attraction ${ }^{10,26}$. Among the two cryptic species, B. tabaci Q preferentially settled and oviposited on TYLCV-infected plants rather than on healthy plants, and had a better overall fitness, including a greater fecundity, survival rate, and female body size, and a shorter developmental time ${ }^{9,28}$.

In this study, a differential response was observed toward virus infection among the two B. tabaci cryptic species. Specifically, for $B$, the virus has no apparent effects on either the performance or the fitness of E. formosa. Increased mortality and parasitism rates, as well as enhanced life history traits, however, were documented in E. formosa parasitizing Q from TYLCV-infected tomatoes. Improved parasitism or predation by the virus-infected host is not without precedent. Belliure et al. noticed an increase in the developmental time of thrips on infected host plants, which led a reduced risk of predation by predatory mites ${ }^{29}$. Infected with Tomato spotted wilt virus, thrips larvae grew too big to be preyed on by the predatory mites. However, when the prey size is not the limiting factor, plant virus could not influence the predation risk (a predatory beetle can consume all sizes of thrips larvae ${ }^{29}$. The seven-spotted ladybug, Coccinella septempunctata, consumed more aphids when the aphids were infected with Rhopalosiphum padi virus ${ }^{30}$. Also, a higher rate of parasitism and the greater overall population suppression by the parasitoid Aphidius colemani were observed when their aphid hosts were infected with Cereal yellow dwarf virus ${ }^{31}$.

Conclusion. A persistently transmitted virus, like TYLCV, can enhance the quality of host plant to attract insect vector and increase the viral transmission ${ }^{32}$. The quality of the insect vector, the host for parasitoids, can be improved accordingly. Higher quality of the host, consequently, can impact the performance of parasitoids and can, potentially, shift their host preference (Figure 3). Previous study showed that TYLCV-infected plants improved the growth, development, and fitness of $\mathrm{Q}$ but decreased the fitness of $\mathrm{B}^{9}$. In this study, when infected, the fitness level of E. formosa decreased in $\mathrm{B}$, whereas both fitness and performance of the parasitic wasp were significantly improved in Q.

The present work showed the improved parasitism of $E$. formosa on the host of $B$. tabaci Q when the virus factor was added. The combined results suggest that the parasitoids may contribute to the suppression of TYLCV in the field by disproportionately influencing the vectors feeding on the infected plants. In addition, for the concurrent control of B. tabaci B and Q in the field, our results are encouraging in the context of integrated pest management, because they suggest that the current biological practice with parasitoids may contribute indirectly to the management of TYLCV by impacting on more competent virus-carrying vectors, B. tabaci $\mathrm{Q}$, and consequently reducing the proportion of vectors in the population that are infectious. 

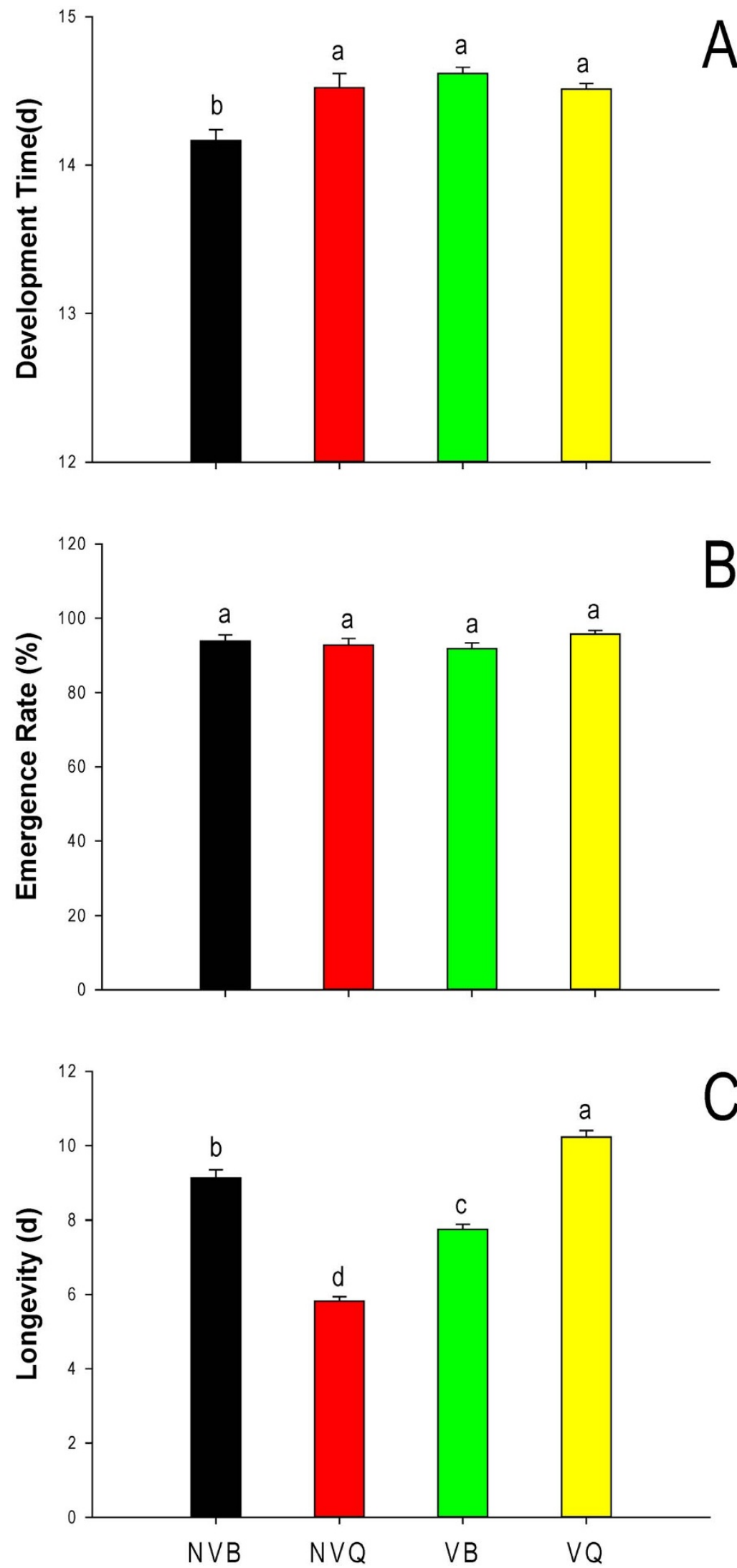

Figure $2 \mid$ The impact of TYLCV and B. tabaci cryptic species on the life history traits of $E$. formosa. To evaluate the potential impacts of plant virus and insect vector on a primary whitefly parasitoid, life history traits, including the developmental time (A), emergence rate (B), and longevity (C), of $E$. formosa were recorded. The $3^{\text {rd }}$ instar nymphs of B. tabaci B and Q cryptic species were reared on healthy (NV) and TYLCV-infected tomato plants (V), respectively. Values (means $\pm \mathrm{SE}$ ) are from three biological replications. Within each panel, different letters indicate significant differences among treatments $(\mathrm{P}<0.05)$. 


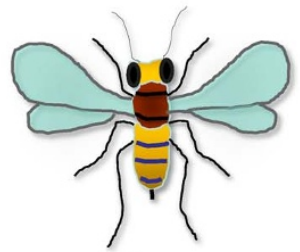

E. formosa

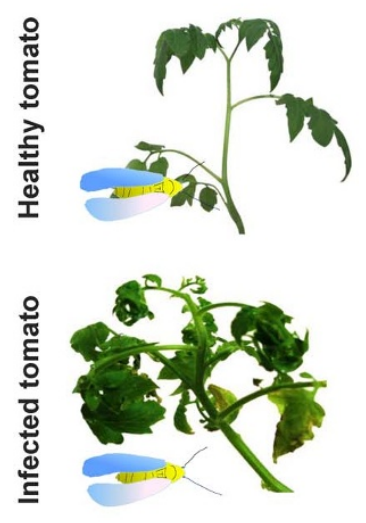

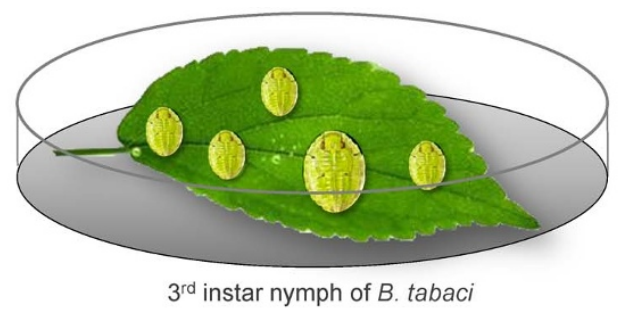

B
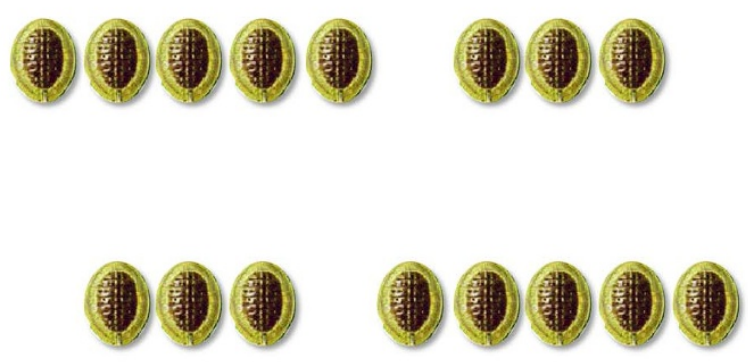

E. formosa pupae

Figure 3 Patterns of parasite behavior in relation to plant pathogen and insect vectors. In this schematic, the parasitoid is an endoparasitoid, E. formosa, the pathogen is a plant virus, Tomato yellow leaf curl virus (infected plant is discoloured in yellow), and the vector is the sweetpotato whitefly B. tabaci B and Q cryptic species. Both insect vector and plant virus have a significant influence on the performance and fitness of $E$. formosa. Parasitic wasp performed better on B. tabaci B than on Q on healthy plants. Whereas, virus induced plant responses influences the behavior and physiology of the insect vector, and consequently exerts its impact on the parasitoids indirectly. For B. tabaci Q, TYLCV had a positive effect on both performance and fitness of $E$. formosa. In contrast, a negative impact on the life history traits of $E$. formosa was observed when B was fed on the infected tomato plants. Please note the number of B. tabaci nymphs infected with E. formosa is purely hypothetical, implicating either positive (more) or negative (less) effects.

\section{Methods}

Insect and parasitoid cultures. Bemisia tabaci $\mathrm{B}$ population was originally collected from an infested cabbage field in Beijing, China in $2004^{33}$, and the Q population was collected from a poinsettia plant in Beijing, China in 2009. Their identities were confirmed by random amplified polymorphic DNA polymerase chain reaction (RAPD-PCR) $)^{34}$. Both B. tabaci populations were maintained on tomato plants in a growth chamber at $27 \pm 1^{\circ} \mathrm{C}, 70 \pm 5 \% \mathrm{RH}$, and a $16 / 8 \mathrm{~L} / \mathrm{D}$ photoperiod.

Encarsia formosa culture was a gift from the Beijing Academy of Agriculture and Forestry Sciences. The parasitic wasp had been maintained on B. tabaci B on tobacco plants for more than five generations. Upon arrival in our laboratory, the original culture was divided into two groups; one culture was maintained on B and the other was maintained on $\mathrm{Q}$.

Plant materials. Tomato (L. esculentum Mill, No. 9 Zhongza) was used as the host plant for B. tabaci B and Q. The tomato plants were grown in the greenhouse and covered with 100-mesh insect-proof screen to exclude whiteflies and other pests.

TYLCV-infected tomato plants were obtained by Agrobacterium tumefaciensmediated inoculation using a cloned TYLCV genome (GenBank accession ID: AM282874). The plants were inoculated at the 3 to 4 true-leaf stage. TYLCV infection of the inoculated tomato plants was confirmed using a set of TYLCV primers C473 and $\mathrm{V}^{3} 1^{35}$. Bemisia tabaci $\mathrm{B}$ and $\mathrm{Q}$ populations were maintained on healthy and TYLCV-infected tomato plants, respectively, when host plants reached 6 to 7 true-leaf stage.

Effects of B. tabaci cryptic species and plant virus on the parasitism of $E$. formosa. The parasitoid-induced B. tabaci mortality, the percentage of $B$. tabaci parasitized, the percentage of $E$. formosa pupae from which adult wasps emerged, $E$. formosa longevity, and E. formosa developmental time were determined using the clip-cages method. $3^{\text {rd }}$-instar nymphs were used in this study because the development of $E$. formosa is more synchronized at this life stage ${ }^{17,36}$. Twenty newly emerged $B$. tabaci adults (B or Q) were placed on the abaxial surface of a selected host leaf of a tomato plant (infected or not infected with TYLCV); the adults and leaf were contained in a leaf clip-cage (one clip cage per plant). After $24 \mathrm{~h}$, the adults were removed, and the eggs were monitored and counted daily until they developed into $3^{\text {rd }}$-instar nymphs. The number of $3^{\text {rd }}$-instar nymphs was then adjusted to 30 per clip cage. One newly emerged $E$. formosa female was then introduced into each leaf clip-cage, and each of the four treatments (two cryptic species and two virus conditions) was represented by 20 replicate clip-cages. The plants with the cages were maintained in growth chambers at $27 \pm 1^{\circ} \mathrm{C}, 70 \pm 5 \% \mathrm{RH}$, and a $14 / 10 \mathrm{~L} / \mathrm{D}$ photoperiod. After $24 \mathrm{~h}$, the adult $E$. formosa was removed from each clip-cage. When parasitized, each $B$. tabaci nymph was turned into one $E$. formosa pupa under the above mentioned experimental conditions. The endpoint measurements, including parasitism rate mortality, and emergence rate were determined for each cohort of $30 \mathrm{~B}$. tabaci nymphs in their respective clip-cage after 6-10 days assay period.

A second experiment was carried out to determine the impact of $B$. tabaci cryptic species and plant virus on E. formosa longevity. This experiment used the same conditions and similar materials as described in the previous paragraph. One newly emerged $E$. formosa female adult was introduced into a clip-cage on a tomato leaf (infected or not infected with TYLCV) infested with $303^{\text {rd }}$-instar nymphs of $B$. tabaci (B or Q). Each of the four treatments (two cryptic species and two virus conditions) was represented by 20 replicate clip-cages. Each day until the wasp died, the wasp in each clip-cage was transferred to a new leaf with $303^{\text {rd }}$-instar nymphs. The longevity of each E. formosa adult was recorded. Both experiments have been independently replicated three times.

Data analysis. Data were first checked for normality and transformed when necessary to meet the assumption of normal distribution. The data for parasitism rate, B. tabaci mortality rate, and $E$. formosa emergence rate were arcsine-square root transformed for analyses. The generalized linear model (GLM, two-way ANOVA) was used to test the effects of $B$. tabaci cryptic species, virus infection status of the tomato plant, and the interaction of cryptic species and virus infection status on the following parameters: $B$. tabaci mortality rate, the percentage of $B$. tabaci parasitized by $E$. formosa, the emergence rate of $E$. formosa adults from pupae, the longevity of E. formosa adults, and E. formosa developmental time. SPSS (version 13.0; SPSS Inc., Chicago, IL, USA) was used for statistical analyses (one-way ANOVA, Tukey's test).

1. Dinsdale, A., Cook, L., Riginos, C., Buckley, Y. M. \& De Barro, P. Refined global analysis of Bemisia tabaci (Hemiptera: Sternorrhyncha: Aleyrodoidea: Aleyrodidae) mitochondrial cytochrome oxidase I to identify species level genetic boundaries. Ann. Entomol. Soc. Am. 103, 196-208 (2010).

2. Xu, J., De Barro, P. J. \& Liu, S. S. Reproductive incompatibility among genetic groups of Bemisia tabaci supports the proposition that the whitefly is a cryptic species complex. Bull.Entomol.Res. 100, 359-366 (2010).

3. De Barro, P. J., Liu, S. S., Boykin, L. M. \& Dinsdale, A. B. Bemisia tabaci: A statement of species status. Annu. Rev. Entomol. 1, 1-19 (2011).

4. Chu, D., Wan, F. H., Zhang, Y. J. \& Brown, J. K. Change in the biotype composition of Bemisia tabaci in Shandong Province of China from 2005 to 2008. Environ. Entomol. 39, 1028-1036 (2010).

5. Pan, H. P. et al. Further spread of and domination by Bemisia tabaci biotype $\mathrm{Q}$ on field crops in China. J. Econ. Entomol. 104, 978-985 (2011).

6. Varma, A. \& Malathi, V. G. Emerging geminivirus problems: a serious threat to crop production. Ann. Appl. Biol. 142, 145-164 (2003). 
7. Brown, J. K. \& Czosnek, H. Whitefly transmission of plant viruses. Adv. Bot. Res. 36, 65-76 (2002).

8. Wu, J. B., Dai, F. M. \& Zhou, X. P. First report of Tomato yellow leaf curl virus in China. Plant Disease 90, 1359-1359 (2006).

9. Pan, H. P. et al. Rapid spread of Tomato yellow leaf curl virus in China is aided differentially by two invasive whiteflies. PLoS ONE 7, e34817 (2012).

10. Liu, B. M. et al. Multiple forms of vector manipulation by a plant-infecting virus: Bemisia tabaci and tomato yellow leaf curl virus. J. Virol. 87, 4929-4937 (2013).

11. Jiang, Y. X., de Blas, C., Barrios, L. \& Fereres, A. Correlation between whitefly (Homoptera: Aleyrodidae) feeding behavior and transmission of tomato yellow leaf curl virus. Ann. Entomol. Soc. Am. 93, 573-579 (2000).

12. Luo, C. et al. Insecticide resistance in Bemisia tabaci biotype Q (Hemiptera: Aleyrodidae) from China. Crop Prot. 29, 429-434 (2010).

13. Li, X. C. et al. Baseline susceptibilities of B- and Q-biotype Bemisia tabaci to anthranilic diamides in Arizona. Pest Manag. Sci. 68, 83-91 (2012).

14. Hoddle, M. S., Van Driesche, R. G. \& Sanderson, J. P. Biology and use of the whitefly parasitoid Encarsia formosa. Annu. Rev. Entomol. 43, 645-69 (1998).

15. Zhang, S. Z., Wan, F. H., Zhang, F. \& Hua, B. Z. Parasitic suitability of two strains of Encarsia formosa on Bemisia tabaci. Chinese J. Biol. Control 19, 149-153 (2003).

16. Qiu, Y. T., Van Lenteren, J. C., Drost, Y. C. \& Posthuma-Doodeman, J. A. M. Lifehistory parameters of Encarsia formosa, Eretmocerus eremicus and E. mundus, aphelinid parasitoids of Bemisia argentifoli (Hemiptera: Aleyrodidae). Eur. J. Entomol. 101, 83-94 (2004).

17. Takahashi, K. M., Berti Filho, E. \& Lourenção, A. L. Biology of Bemisia tabaci (Genn.) B-biotype and parasitism by Encarsia formosa (Gahan) on collard, soybean and tomato plants. Sci. Agr. 65, 639-642 (2008).

18. Grille, G., Lorenzo, M. E., Burla, J. P., Franco, J. \& Basso, C. Parasitoid Niches of Encarsia formosa and Encarsia Lycopersici (Hymenoptera: Aphelinidae) Exploiting Trialeurodes vaporariorum (Hemiptera: Aleyrodidae). Fla. Entomol 95, 1024-1030 (2012).

19. Elbaz, M., Lahav, N., \& Morin, S. Evidence for pre-zygotic reproductive barrier between the B and Q biotypes of Bemisia tabaci (Hemiptera: Aleyrodidae). B. Entomol. Res. 100, 581-590 (2010).

20. Tsueda, H., \& Tsuchida, K. Reproductive differences between Q and B whiteflies, Bemisia tabaci, on three host plants and negative interactions in mixed cohorts. Entomol. Exp. Appl. 141, 197-207 (2011).

21. Wang, J. H., Luo, C. \& Liu, T. X. Effects of Bemisia tabaci (Hemiptera: Aleyrodidae) biotype on host selecton and development of Encarsia Sophia (Hymenoptera: Aphelinedae). Acta. Entomol. Sin. 54, 687-693 (2011).

22. Chu, D. et al. The introduction of the exotic biotype Q of Bemisia tabaci from the Mediterranean region into China on ornamental crops. Fla. Entomol. 89, 168-174 (2006).

23. Wang, Z. Y., Yan, H. F., Yang, Y. H. \& Wu, Y. D. Biotype and insecticide resistance status of the whitefly Bemisia tabaci from China. Pest Manag. Sci. 66, 1360-1366 (2010).

24. Zang, L. S. \& Liu, T. X. Host-feeding of three parasitoid species on Bemisia tabaci biotype B and implications for whitefly biological control. Entomol. Exp. Appl. 127, 55-63 (2008).

25. Stafford, C. A., Walker, G. P. \& Ullman, D. E. Infection with a plant virus modifies vector feeding behavior. P. Natl. Acad. Sci. USA. 108, 9350-9355 (2011).

26. Fang, Y. et al. Tomato yellow leaf curl virus alters the host preferences of its vector Bemisia tabaci. Sci. Rep. 3, 2876 (2013).

27. Luan, J. B. et al. Suppression of terpenoid synthesis in plants by a virus promotes its mutualism with vectors. Eco. Lett. 16, 390-398 (2013).

28. Chen, G. et al. Virus infection of a weed increases vector attraction to and vector fitness on the weed. Sci. Rep. 3, 2253 (2013).
29. Belliure, B., Janssen, A. \& Sabelis, M. W. Herbivore benefits from vectoring plant virus through reduction of period of vulnerability to predation. Oecologia. 156, 797-806 (2008).

30. Ban, L., Ahmed, E., Ninkovic, V., Delp, G. \& Glinwood, R. Infection with an insect virus affects olfactory behaviour and interactions with host plant and natural enemies in an aphid. Entomol. Exp. Appl. 127, 108-117 (2008).

31. de Oliveira, C. F., Long, E. Y. \& Finke, D. L. A negative effect of a pathogen on its vector? A plant pathogen increases the vulnerability of its vector to attack by natural enemies. Oecologia 174, 1169-1177 (2014).

32. Mauck, K., Bosque-Pérez, N. A., Eigenbrode, S. D., DeMoraes, C. M. \& Mescher, M. C. Transmission mechanisms shape pathogen effects on host-vector interactions: evidence from plant viruses. Funct. Ecol. 26, 1162-1175 (2012).

33. Xie, W. et al. Induction effects of host plants on insecticide susceptibility and detoxification enzymes of Bemisia tabaci (Hemiptera: Aleyrodidae). Pest Manag. Sci. 67, 87-93 (2011).

34. Wu, X. X., Hu, D. X., Li, Z. X. \& Shen, Z. M. Using RAPD-PCR to distinguish biotypes of Bemisia tabaci (Homoptera: Aleyrodidae) in China. Entomol. Sin. 9, 1-8 (2002).

35. Ghanim, M., Morin, S., Zeidan, M. \& Czosnek, H. Evidence for transovarial transmission of Tomato Yellow Leaf Curl Virus by its vector, the whitefly Bemisia tabaci. Virology 240, 295-303 (1998).

36. Hu, J. S., Gelman, D. B. \& Blackburn, B. B. Age-specific interaction between the parasitoid, Encarsia formosa and its host, the silverleaf whitefly, Bemisia tabaci (Strain B). J. Insect Sci. 3, 28 (2003).

\section{Acknowledgments}

Special thanks go to John J. Obrycki (University of Kentucky) for his comments and English editing. This research was supported by the 973 Program (2013CB127602), the National Natural Science Foundation of China (31171857), the China Agriculture Research System (CARS-26-10), and the Beijing Key Laboratory for Pest Control and Sustainable Control. The granting agencies had no role in study design, data collection and analysis, decision to publish, or manuscript preparation.

\section{Author contributions}

S.L.W., Y.J.Z., X.G.Z. and X.Y.L. designed the experiment. X.Y.L. performed the experiment. Q.J.W., S.L.W., W.X. and W.S.X. contributed reagents/materials. X.Y.L., S.L.W., X.G.J. and X.G.Z. wrote the paper. All authors reviewed the manuscript.

\section{Additional information}

Supplementary information accompanies this paper at http://www.nature.com/ scientificreports

Competing financial interests: The authors declare no competing financial interests. How to cite this article: Liu, X. et al. Effects of plant virus and its insect vector on Encarsia formosa, a biocontrol agent of whiteflies. Sci. Rep. 4, 5926; DOI:10.1038/srep05926 (2014).

This work is licensed under a Creative Commons Attribution-NonCommercialNoDerivs 4.0 International License. The images or other third party material in this article are included in the article's Creative Commons license, unless indicated otherwise in the credit line; if the material is not included under the Creative Commons license, users will need to obtain permission from the license holder in order to reproduce the material. To view a copy of this license, visit http:// creativecommons.org/licenses/by-nc-nd/4.0/ 